\title{
Thermohaline structure and circulation in the upper layers of the southern Bay of Bengal during BOBMEX-Pilot (October - November 1998)
}

\author{
V Ramesh Babu, V S N Murty, L V G Rao, C V Prabhu and V Tilvi \\ National Institute of Oceanography, Dona Paula, Goa 403004 , India
}

\begin{abstract}
Hydrographic data collected on board ORV Sagar Kanya in the southern Bay of Bengal during the BOBMEX-Pilot programme (October - November 1998) have been used to describe the thermohaline structure and circulation in the upper $200 \mathrm{~m}$ water column of the study region. The presence of seasonal Inter-Tropical Convergence Zone (ITCZ) over the study area, typically characterized with enhanced cloudiness and flanked by the respective east/northeast winds on its northern part and west/southwest winds on its southern part, has led to net surface heat loss of about $55 \mathrm{~W} / \mathrm{m}^{2}$. The sea surface dynamic topography relative to $500 \mathrm{db}$ shows that the upper layer circulation is characterised by a cyclonic gyre encompassing the study area. The eastward flowing Indian Monsoon Current (IMC) between $5^{\circ} \mathrm{N}$ and $7^{\circ} \mathrm{N}$ in the south and its northward branching along $87^{\circ} \mathrm{E}$ up to $13^{\circ} \mathrm{N}$ appear to feed the cyclonic gyre. The Vessel-Mounted Acoustic Doppler Current Profiler (VM-ADCP) measured currents confirm the presence of the cyclonic gyre in the southern Bay of Bengal during the withdrawing phase of the southwest monsoon from the northern/central parts of the Bay of Bengal.
\end{abstract}

\section{Introduction}

The Bay of Bengal and Monsoon Experiment (BOBMEX) is a national scientific activity under the Indian Climate Research Programme (ICRP) designed for the summer monsoon season of 1999 in order to improve the understanding of intra-seasonal ocean-atmosphere coupling over the energetically active Bay of Bengal through multi-ship surveys. However, a pilot experiment called the BOBMEXPilot was conducted during October - November, 1998 over the southern Bay of Bengal to test the sophisticated equipment meant for use in the main BOBMEX field observations. During the BOBMEX-Pilot period the southwest monsoon conditions still prevailed with the presence of strong westerly/southwesterly winds and inclement weather with active ITCZ and intense convection. Temperature and salinity observations using CTD and the Vessel-Mounted Acoustic Doppler Current Profiler (VM-ADCP) measured direct currents during BOBMEX-Pilot have given us a good opportunity to describe the thermohaline fields, currents and circulation in the southern Bay of Bengal during October - November 1998. This study has an added advantage of direct current measurements by VM-ADCP to compare with the derived geostrophic currents as was hitherto practiced by earlier investigators (Murty et al 1992, 1993, 1996; Suryanarayana et al 1993; Varkey et al 1996; Gopalkrishna et al 1996; Sarma et al 1999). Their studies mainly deal with the hydrography and circulation based on dynamic topography fields in the northern and central parts of the Bay of Bengal during southwest and postsouthwest monsoon seasons. Some of these studies address the intra-seasonal variability of volume transports across selected sections. In this paper, we present the thermohaline structure and circulation in the upper layers of southern Bay of Bengal at the time of the southwest monsoon receding from the Bay of Bengal.

Keywords. Bay of Bengal; thermohaline circulation; Indian Monsoon Current; BOBMEX. 


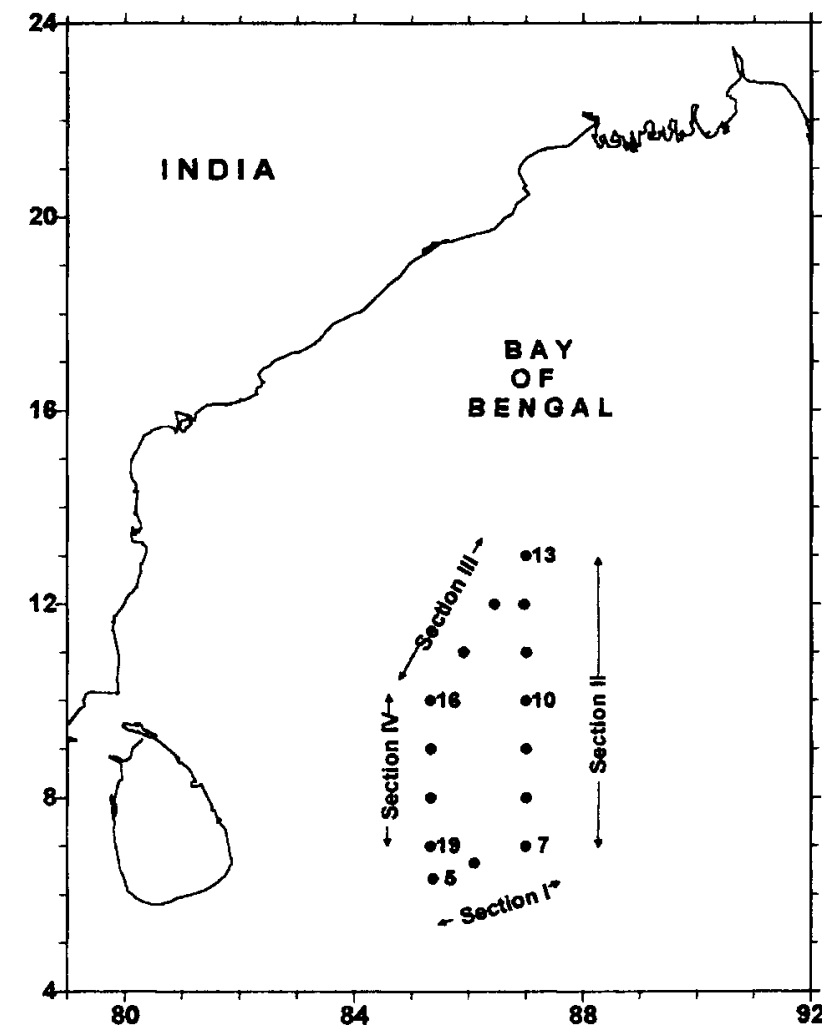

Figure 1. Study area showing CTD station locations during October - November, 1998 (BOBMEX-Pilot).

\section{Data and methods}

The locations of hydrographic stations occupied during BOBMEX-Pilot are shown in figure 1. The Sea-Bird CTD (conductivity-temperature-depth) probe was operated at these locations to obtain temperature and salinity profiles. CTD rosette was used to collect water samples from various depths for salinity and chemical analysis. On board AUTOSAL (Guildline, USA), calibrated with standard sea water, was used to obtain the salinity. At three locations (\#7, \#10 and \#11) representing the southern, central and northern parts of the study area, 1-2 day time-series CTD observations were also carried out at 3-hour intervals. The CTD data were processed using SEASOFT (version 4.0) software and the CTD salinity values were corrected with the help of regression equations developed after comparing the CTD salinity values with the AUTOSAL (accuracy: $\pm 0.001 \mathrm{psu}$ ) salinity values. Routine surface meteorological observations (wind speed and direction, atmospheric pressure, air temperature and relative humidity) were recorded at 10-minute intervals by the on board Automatic Weather Station (AWS). The treatment of AWS data together with the sea surface temperature (SST) is outlined by Murty et al. (2000). The bulk-aerodynamic formulae

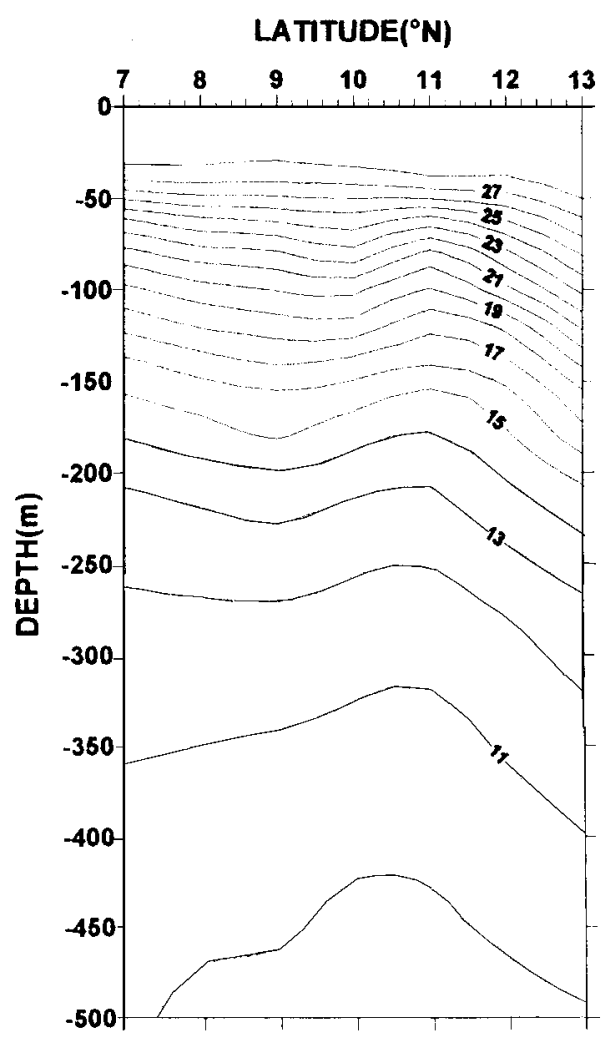

(a)

\section{LONGITUDE('N)}

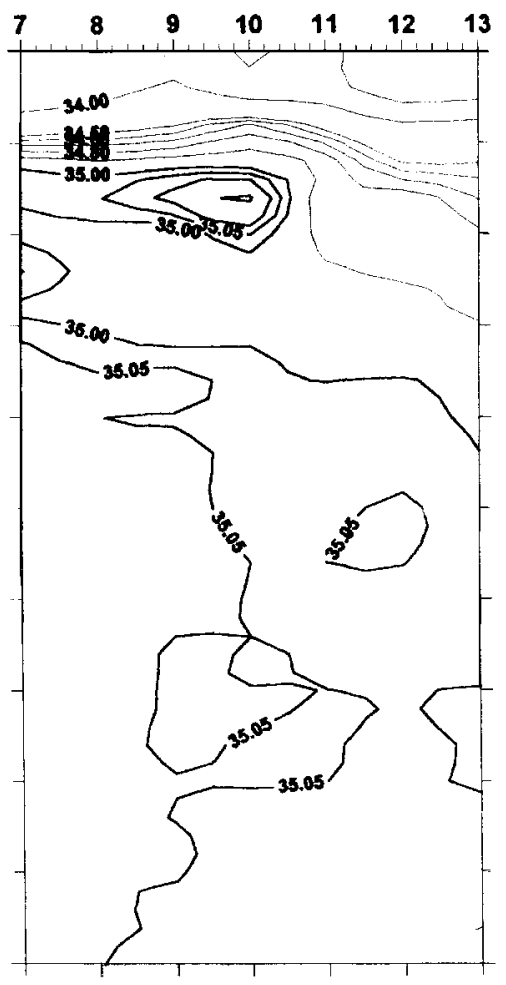

(b)

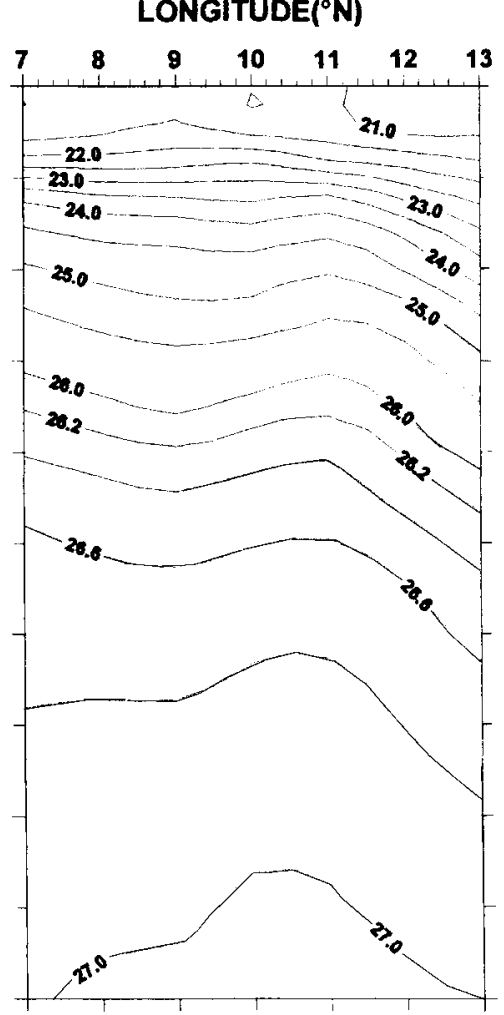

(c)

Figure 2. (a) Upper layer thermal structure, (b) salinity and (c) potential density along section II ( $87^{\circ} \mathrm{E}$ longitude) during BOBMEX-Pilot. 
are used to estimate the surface heat fluxes (latent heat, sensible heat and effective back radiation) following the methodology of Stevenson (1982) and Sarma et al. (1997). The AWS measured global solar radiation data were used to estimate the net heat flux at the sea surface during the observational period in the study area.
3. Results and discussion

\subsection{Upper ocean thermal structure}

Figure 2(a) presents the upper ocean thermal structure along $87^{\circ} \mathrm{E}$ between $7^{\circ} \mathrm{N}$ and $13^{\circ} \mathrm{N}$. The surface mixed layer is around $30 \mathrm{~m}$ and deepens to $50 \mathrm{~m}$ at
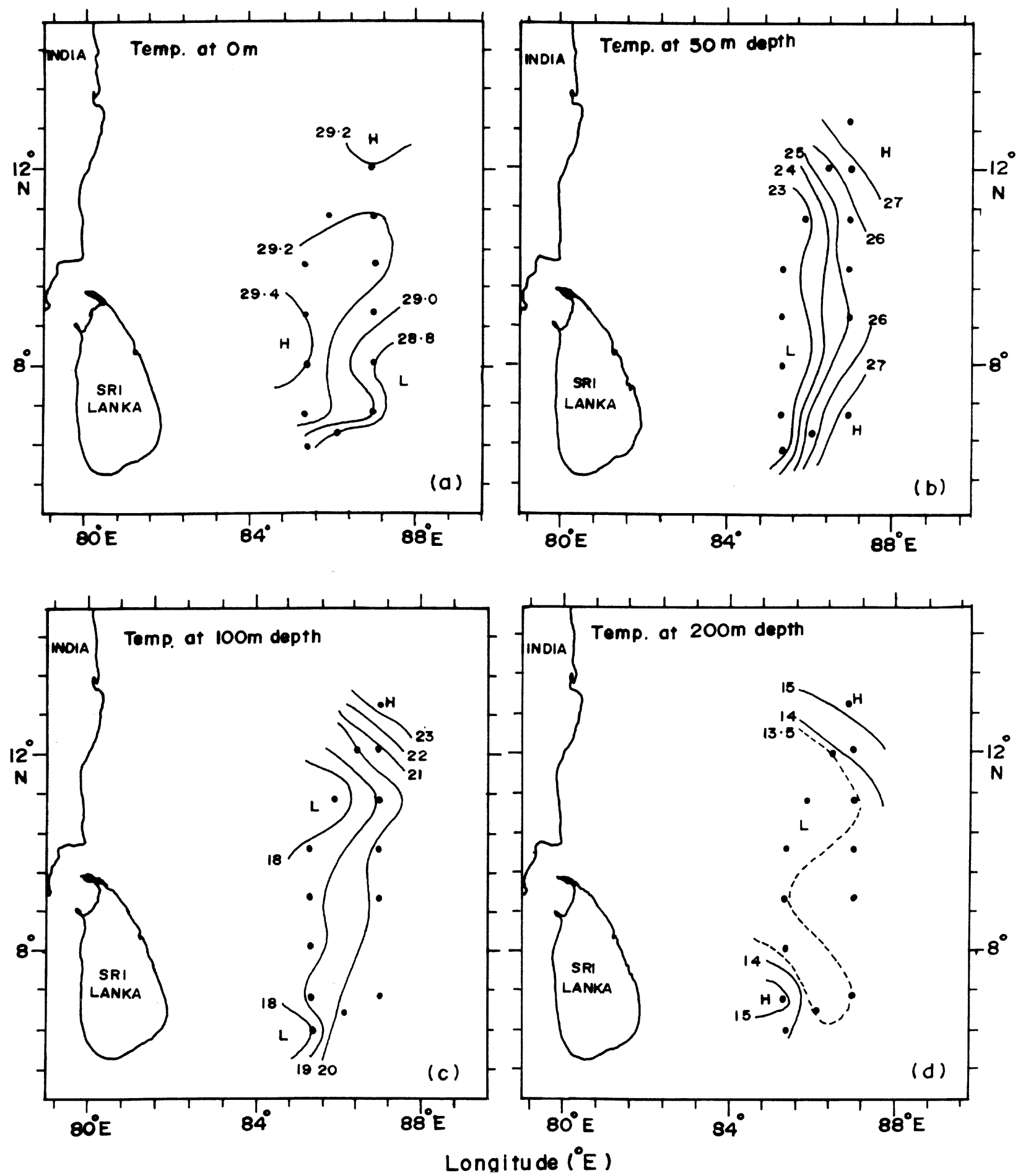

Figure 3. Distribution of temperature at various depths: (a) sea surface, (b) $50 \mathrm{~m}$, (c) $100 \mathrm{~m}$ and (d) $200 \mathrm{~m}$ during BOBMEX Pilot. 
$13^{\circ} \mathrm{N}$. Doming of isotherms is the conspicuous feature from a $500 \mathrm{~m}$ depth to the base of the surface mixed layer. The vertical temperature gradients are relatively stronger on the northern part of the dome suggesting an intense westward flow between $11^{\circ} \mathrm{N}$ and $13^{\circ} \mathrm{N}$.

Figures $3(\mathrm{a}-\mathrm{d})$ show the temperature distribution at sea surface at a depth of $50 \mathrm{~m}, 100 \mathrm{~m}$, and $200 \mathrm{~m}$. Sea surface temperature (SST) varies from $28.8^{\circ} \mathrm{C}$ to $29.4^{\circ} \mathrm{C}$ with cold waters to the east of $86^{\circ} \mathrm{E}$ and warmer $\left(>29.2^{\circ} \mathrm{C}\right)$ to the west of $86^{\circ} \mathrm{E}$. The spatial variation in SST is of the same order as its diurnal range at three time series locations (Murty et al. 2000). At $50 \mathrm{~m}$, temperature varies between $23^{\circ} \mathrm{C}$ and $27^{\circ} \mathrm{C}$ and the isotherms exhibited near-meridional orientation with strong westward directed zonal temperature gradient which is opposite to that at the sea surface. At $100 \mathrm{~m}$, the temperature variation is about $5^{\circ} \mathrm{C}$ between $11^{\circ} \mathrm{N}$ and $13^{\circ} \mathrm{N}$ and the zonal temperature gradient weakens from that at $50 \mathrm{~m}$ south of $11^{\circ} \mathrm{N}$. At $200 \mathrm{~m}$ depth, the temperature variation is marginal $\left(1.5^{\circ} \mathrm{C}\right)$ from $13.5^{\circ} \mathrm{C}$ to $15^{\circ} \mathrm{C}$ and over a larger part of study area, the temperature is around $13.5^{\circ} \mathrm{C}$.

\subsection{Upper ocean salinity structure}

Near-surface salinity is less on the northern part of the section and the isohalines follow the pattern of isotherms in the upper $75 \mathrm{~m}$ (figure $2 \mathrm{~b}$ ). However a cell of high salinity (35.0-35.10) occupies 75-100 m depth interval between $8^{\circ} \mathrm{N}$ and $10^{\circ} \mathrm{N}$. This high salinity cell lies along $24.5 \sigma_{\theta}$ isopycnal (figure 2c) and can be identified as the Arabian Sea High Salinity Watermass (ASHSW). A portion of Bay of Bengal high salinity layer of salinity greater than $35.05 \mathrm{psu}$ is present in the depth interval $150-500 \mathrm{~m}$ in the south and the layer thickness decreases northward followed by a decrease in the salinity of this layer.

Figures $4(\mathrm{a}-\mathrm{d})$ present the spatial variation of salinity in the upper $200 \mathrm{~m}$. The sea surface salinity varies from 32.0 to $34.0 \mathrm{psu}$ and the zonal gradient of salinity is directed westward (figure 4a) which is opposite to the zonal gradient of SST (figure 3a). The
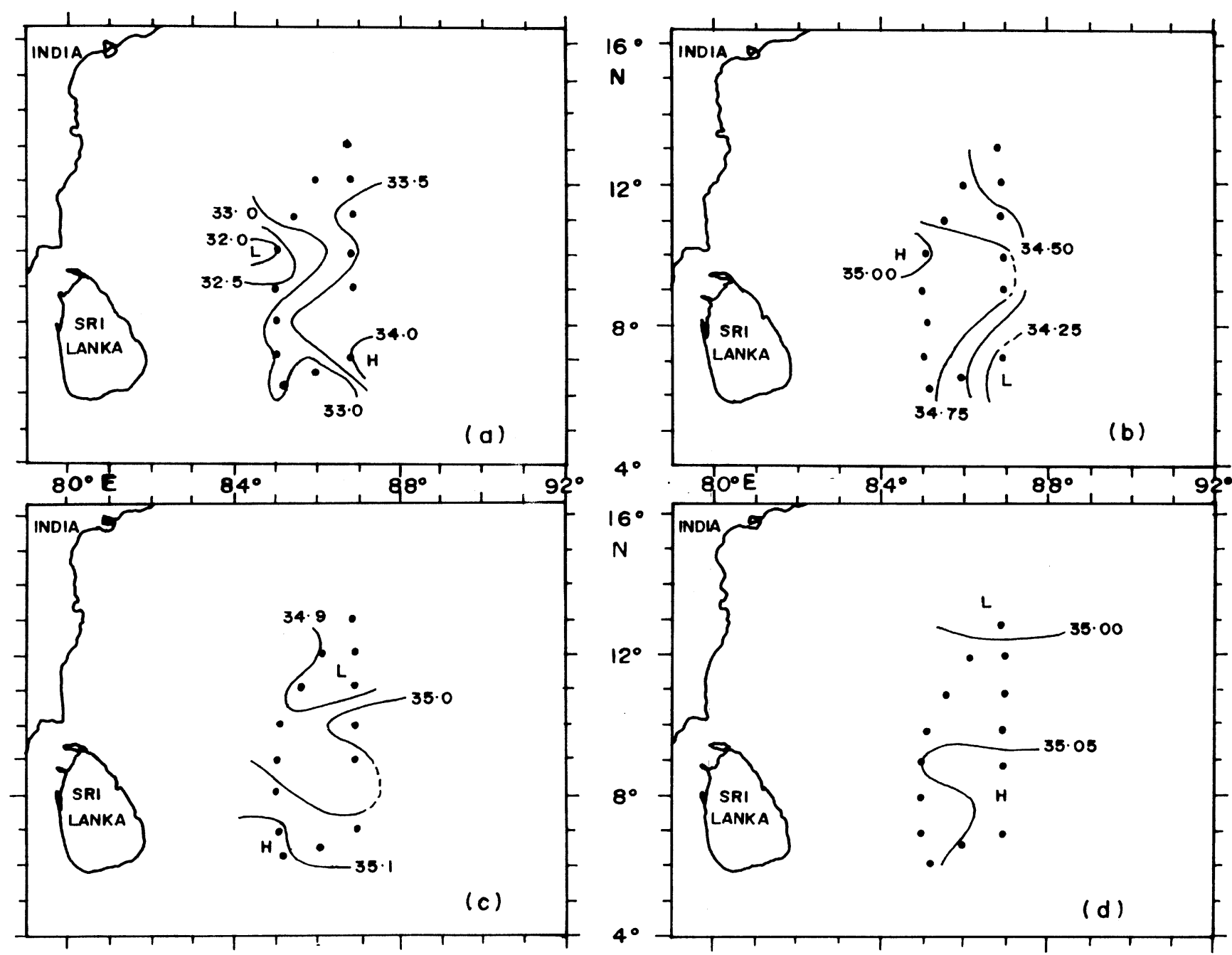

Figure 4. Same as at figure 3, but for salinity during BOBMEX Pilot. 

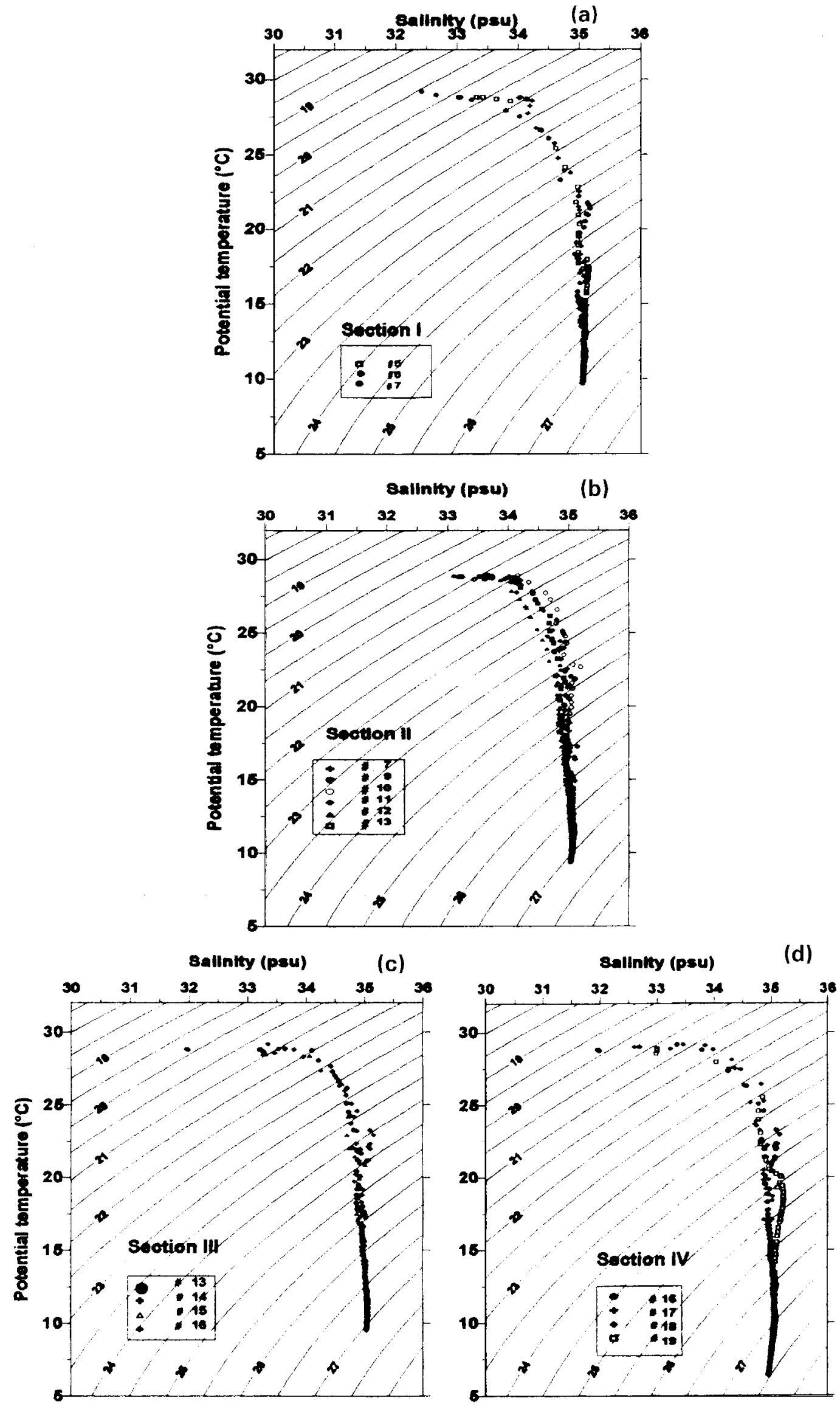

Figure 5. Watermass structure at the CTD stations along section I (a), section II (b), section III (c) and section IV (d) during BOBMEX-Pilot. 
surface waters thus exhibit different T-S relations; warmer, saline waters in the east and cold, less saline waters in the west. At and below $50 \mathrm{~m}$, the salinity variations are both reduced and reversed, and the waters are characterised by different T-S relationship (warm and less saline in the east and cold and saline in the west) from that at the surface (figure $4 \mathrm{~b}$ ). However, at $100 \mathrm{~m}$ and $200 \mathrm{~m}$ depth, the salinity gradient is directed northward with higher salinity waters in the south (figure 4c and d).

\subsection{Watermass structure}

The watermass structure of the study area during the study period is represented by T-S diagrams drawn using the CTD data at the stations along the 4 sections (figures $5 \mathrm{a}-\mathrm{d}$ ). The near surface layer is characterised by warm and halocline and a salinity maximum is encountered between the 24.0 and 24.5 isopycnals at subsurface depths. This high salinity water is identified as the Arabian Sea High Salinity
Watermass (ASHSW) advecting into the Bay under the influence of the Indian Monsoon Current (IMC). In the south, the ASHSW is located between 24.5 and $25.0 \sigma_{\theta}$ isopycnals with reduced salinity towards the north.

\subsection{Upper ocean currents and circulation}

Figures $6(\mathrm{a}-\mathrm{d})$ represent the dynamic topography maps at various depths relative to $500 \mathrm{db}$. The near surface circulation at $15 \mathrm{~m}$ (figure 6a) shows a northward flow encompassing the study area up to $11^{\circ} \mathrm{N}$ where it turns northwestward between $11^{\circ} \mathrm{N}$ and $13^{\circ} \mathrm{N}$. The associated geostrophic velocity is doubled in its magnitude between $11^{\circ} \mathrm{N}$ and $13^{\circ} \mathrm{N}$ when compared to its magnitude in the south as seen from the crowding of isolines of dynamic topography. The geostrophic circulation weakens with depth, though the presence of strong currents associated with the northwestward flow is consistent with depth. At $200 \mathrm{~m}$ depth, (figure 6d) the circulation shows a nearly closed cyclonic gyre encompassing the study area.
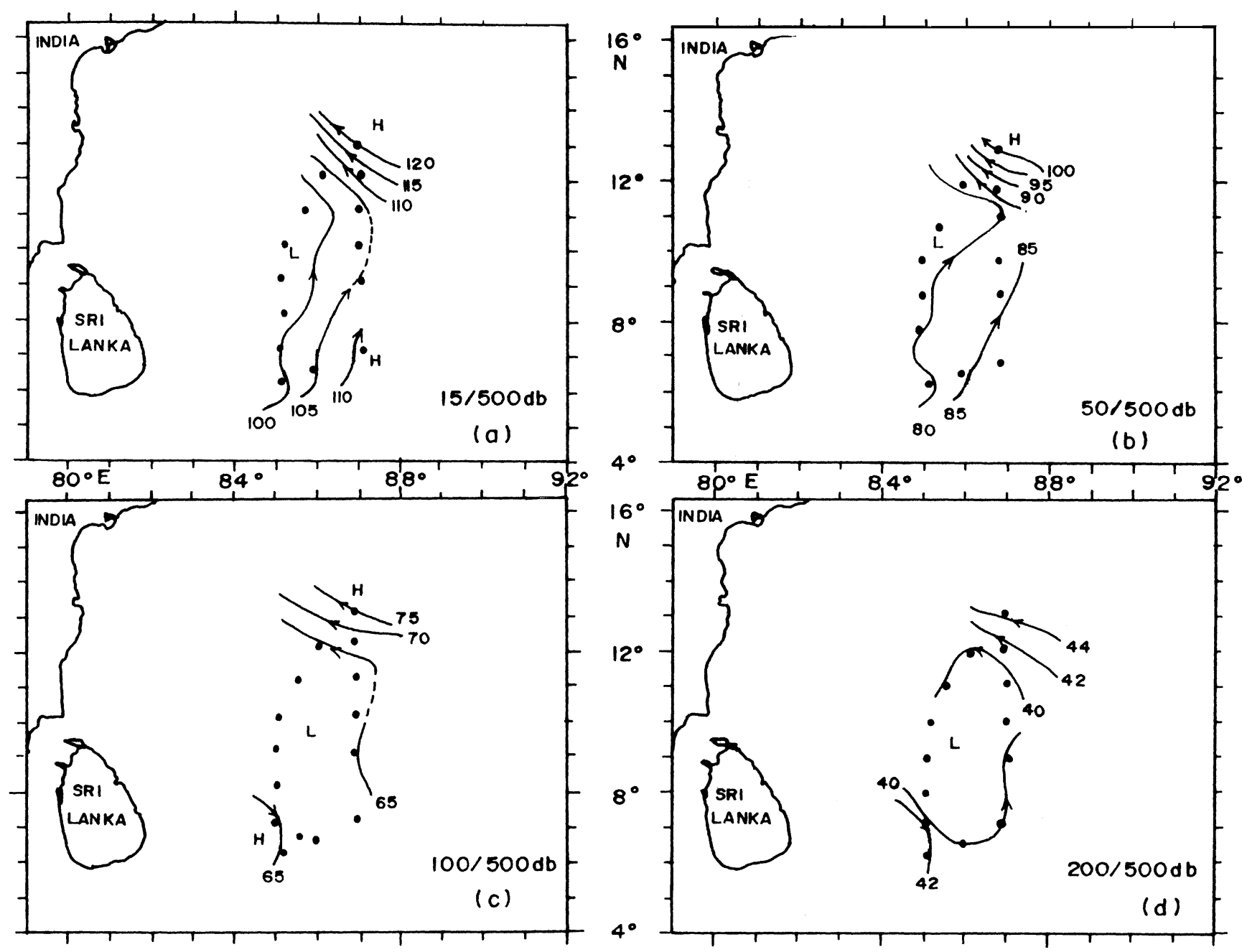

Figure 6. Dynamic topography (dyn.cm) maps relative to $500 \mathrm{db}$ at various depths: (a) sea surface, (b) $50 \mathrm{~m},(\mathbf{c}) 100 \mathrm{~m}$ and (d) $200 \mathrm{~m}$, during BOBMEX-Pilot. 

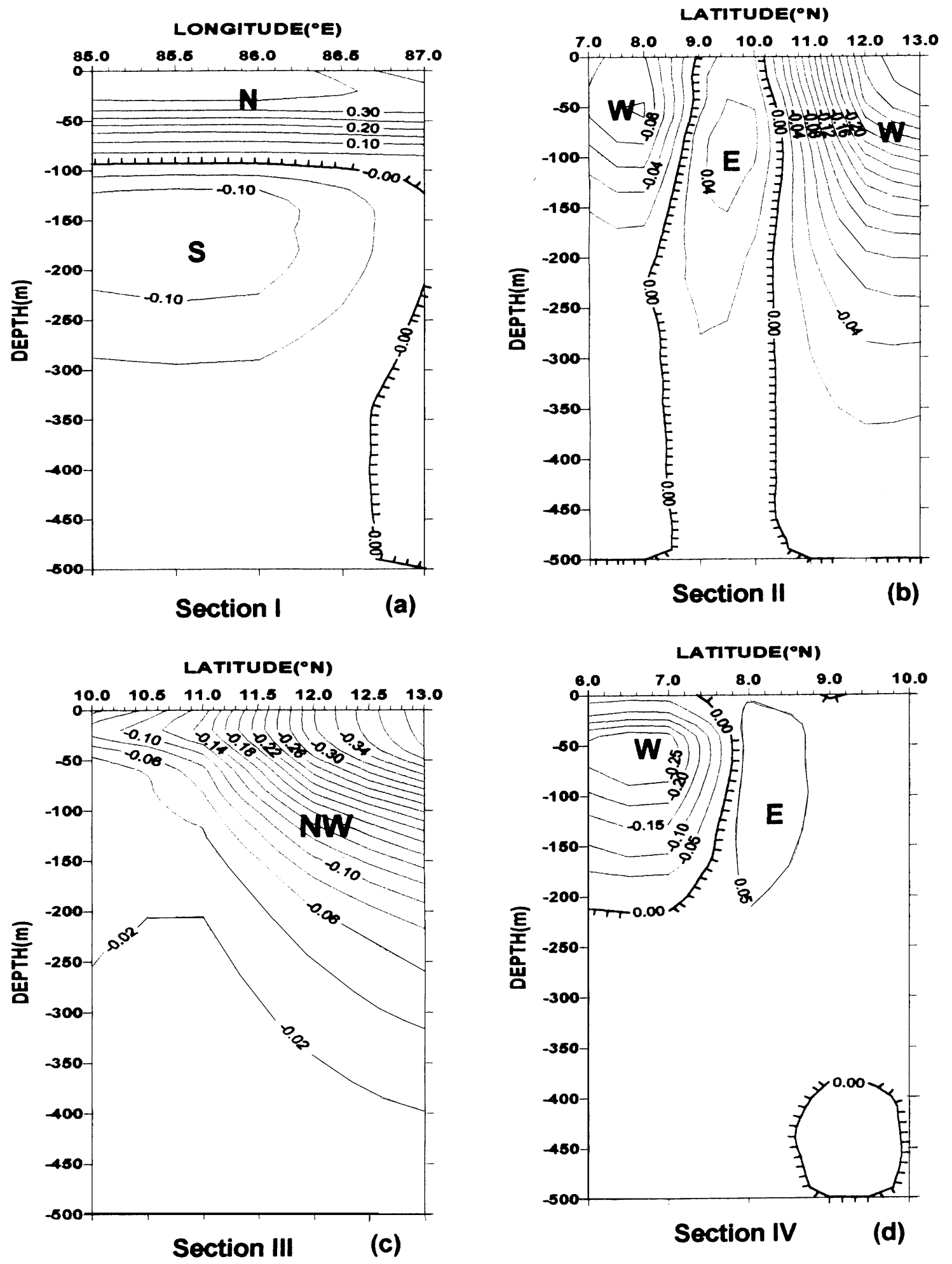

Figure 7. Upper layer geostrophic current (m/s) structure along sections I (a), section II (b), section III (c) and section IV (d) during BOBMEX Pilot. In (a) letter N(S) stands for northward (southward) flow. In (b) and (d) letter w (E) stands for westward (eastward) flows. In (c), NW stands for northwestward flows.

The above flow pattern in the upper $200 \mathrm{~m}$ water column suggests that the divergence of the waters is more intense below $100 \mathrm{~m}$ depth and weakens upward to the surface. This indicates that horizontal convergence prevails at the sea surface. This is more evident from the differential water characteristics at the sur- face across the study area and the near-meridional orientation of the thermohaline fields and the northward flow in the upper $100 \mathrm{~m}$ layer.

The geostrophic velocity structure in the upper $500 \mathrm{~m}$ along the sections I to IV is shown in figure 7(ad). Along section I, between $85^{\circ}$ and $87^{\circ} \mathrm{E}$, two layer 

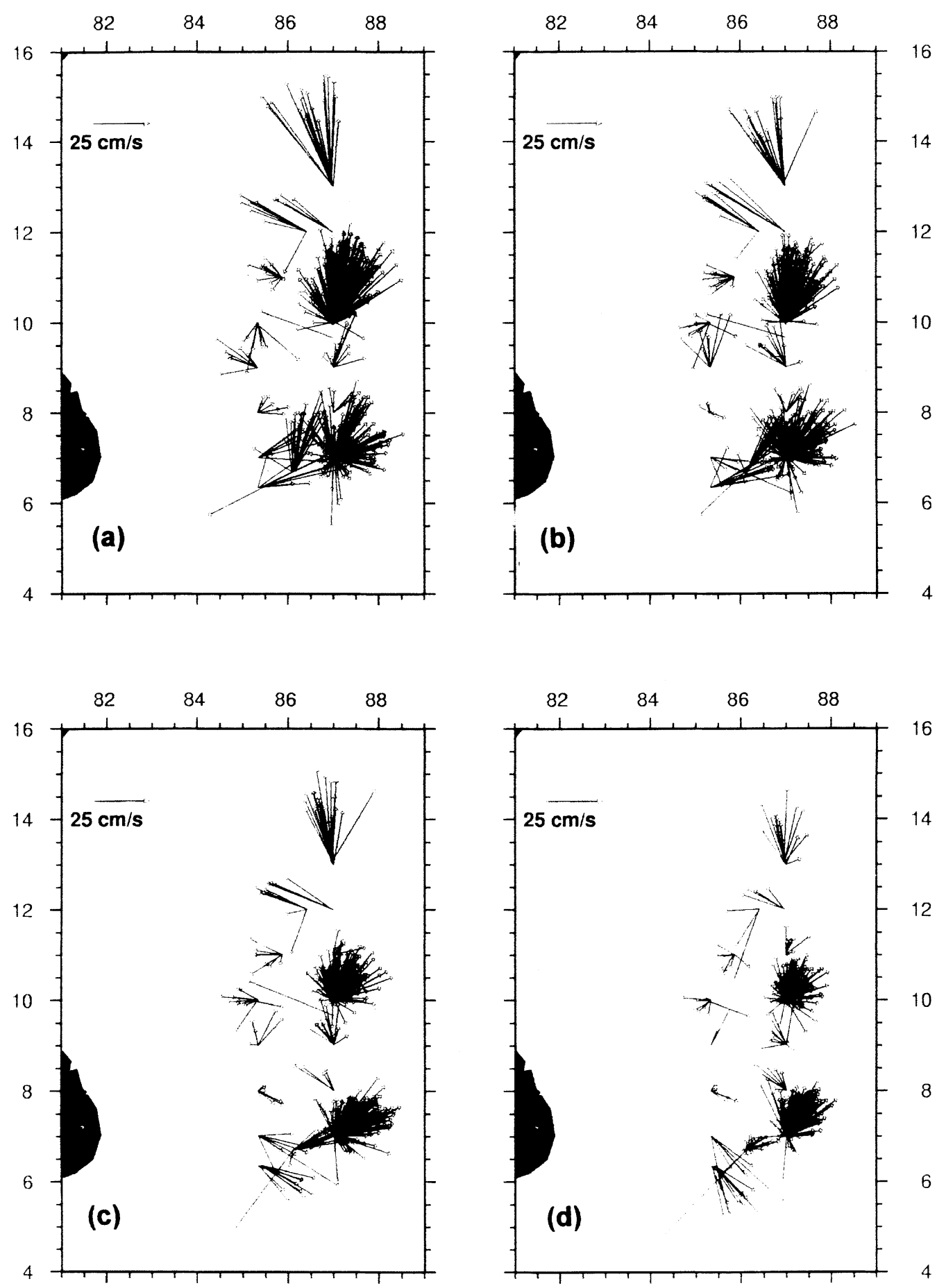

Figure 8. VM-ADCP measured ocean current vectors at the CTD stations at various depths: (a) $31 \mathrm{~m}$, (b) $51 \mathrm{~m},(\mathbf{c}) 100 \mathrm{~m}$ and (d) $200 \mathrm{~m}$ during BOBMEX-Pilot. Note the cluster of vectors at $7^{\circ} \mathrm{N}, 10^{\circ} \mathrm{N}$ and $13^{\circ} \mathrm{N}$ represent the time-series observations over a period of $48 \mathrm{hr}, 48 \mathrm{hr}$ and $24 \mathrm{hr}$ respectively.

current structure-predominant northward flow with higher velocity $(35 \mathrm{~cm} / \mathrm{s})$ at the surface in the upper $100 \mathrm{~m}$ and weaker $(10 \mathrm{~cm} / \mathrm{s})$ southward flow between 150 and $200 \mathrm{~m}$ depth is present. This change in the flow pattern with depth is also evident from the change in the direction of Indian Monsoon Current (IMC) with depth (current shear) as seen in the VMADCP currents-NE vectors in the upper $100 \mathrm{~m}$ and $\mathrm{SE}$ vectors at $100 \mathrm{~m}$ and $200 \mathrm{~m}$ (figure $8 \mathrm{a}-\mathrm{d}$ ). Along section II, between $7^{\circ} \mathrm{N}$ and $13^{\circ} \mathrm{N}$, the flow is predominantly westward and embedded in it is a weak $(4 \mathrm{~cm} / \mathrm{s})$ eastward flow between $9^{\circ} \mathrm{N}$ and $10^{\circ} \mathrm{N}$. The westward flow attains higher velocity $(40 \mathrm{~cm} / \mathrm{s})$ near the surface in the north between $12^{\circ}$ and $13^{\circ} \mathrm{N}$. Along section III, between $10^{\circ} \mathrm{N}$ and $13^{\circ} \mathrm{N}$ only northwestward flow is present throughout the section. However, it is interesting to note that this northwestward current attains higher surface velocity 

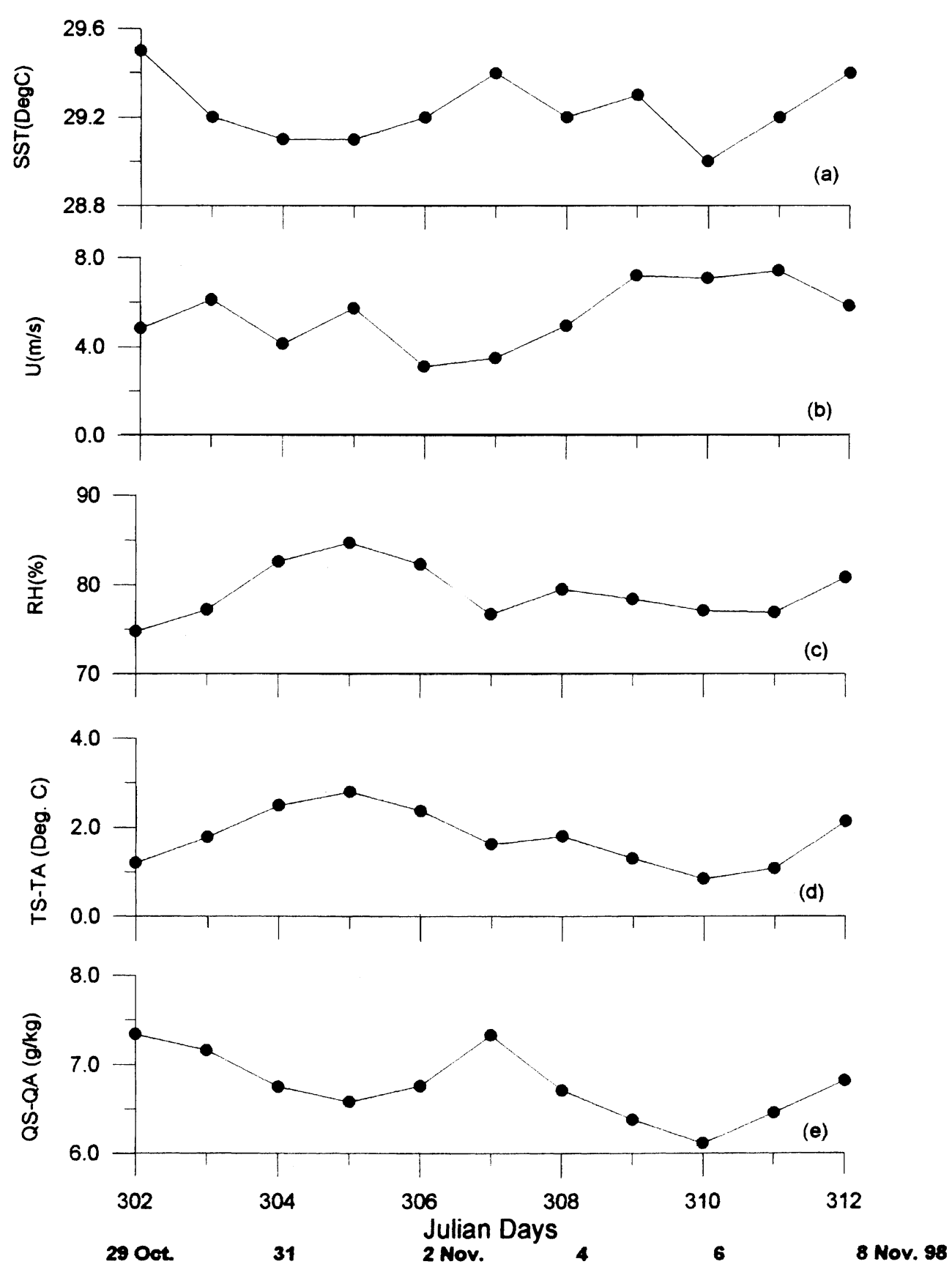

Figure 9. Along the track daily variation of (a) sea surface temperature, (b) wind speed, (c) relative humidity, (d) sea minus air temperature at $10 \mathrm{~m}$ height above the surface and (e) sea minus air specific humidity difference at $10 \mathrm{~m}$ height above surface during BOBMEX-Pilot.

$(40 \mathrm{~cm} / \mathrm{s})$ at the northern part of the section and extends to greater depth. $(\sim 400 \mathrm{~m})$. Its velocity weakens towards southeast. The VM-ADCP currents also confirm this pattern of currents. Along section $\mathrm{IV}$, (figures $8 \mathrm{a}-\mathrm{d}$ ) strong westward flow with its core $(\sim 25 \mathrm{~cm} / \mathrm{s})$ at subsurface depths $(\sim 50 \mathrm{~m})$ is noticed between $6^{\circ} \mathrm{N}$ and $8^{\circ} \mathrm{N}$ while weaker eastward flow occurs north of $8^{\circ} \mathrm{N}$.

The VM-ADCP measured currents at the CTD station locations are presented for four depths $(31,51$, $100 \& 200 \mathrm{~m}$ ) in the upper $200 \mathrm{~m}$ layer (figures $8 \mathrm{a}-\mathrm{d}$ ). Details of VM-ADCP data processing are given in
Murty et al. (2000). The depth bin of measured currents is $31 \mathrm{~m}$. The monthly mean as well as 10 day mean ship drift currents during the month of October reveal eastward currents in the south $\left(5^{\circ} \mathrm{N}-7^{\circ} \mathrm{N}\right)$ and northward currents along $87^{\circ} \mathrm{E}$ (Cutler and Swallow 1984). The VM-ADCP currents at $31 \mathrm{~m}$ also indicate eastward currents in the southern bay including at the time series locations (figure 8a). These eastward currents represent the Indian Monsoon Current (IMC) with velocity between 25 and $50 \mathrm{~cm} / \mathrm{s}$. The turning of the IMC towards north along $87^{\circ} \mathrm{E}$ is also evident in the VM-ADCP currents. 


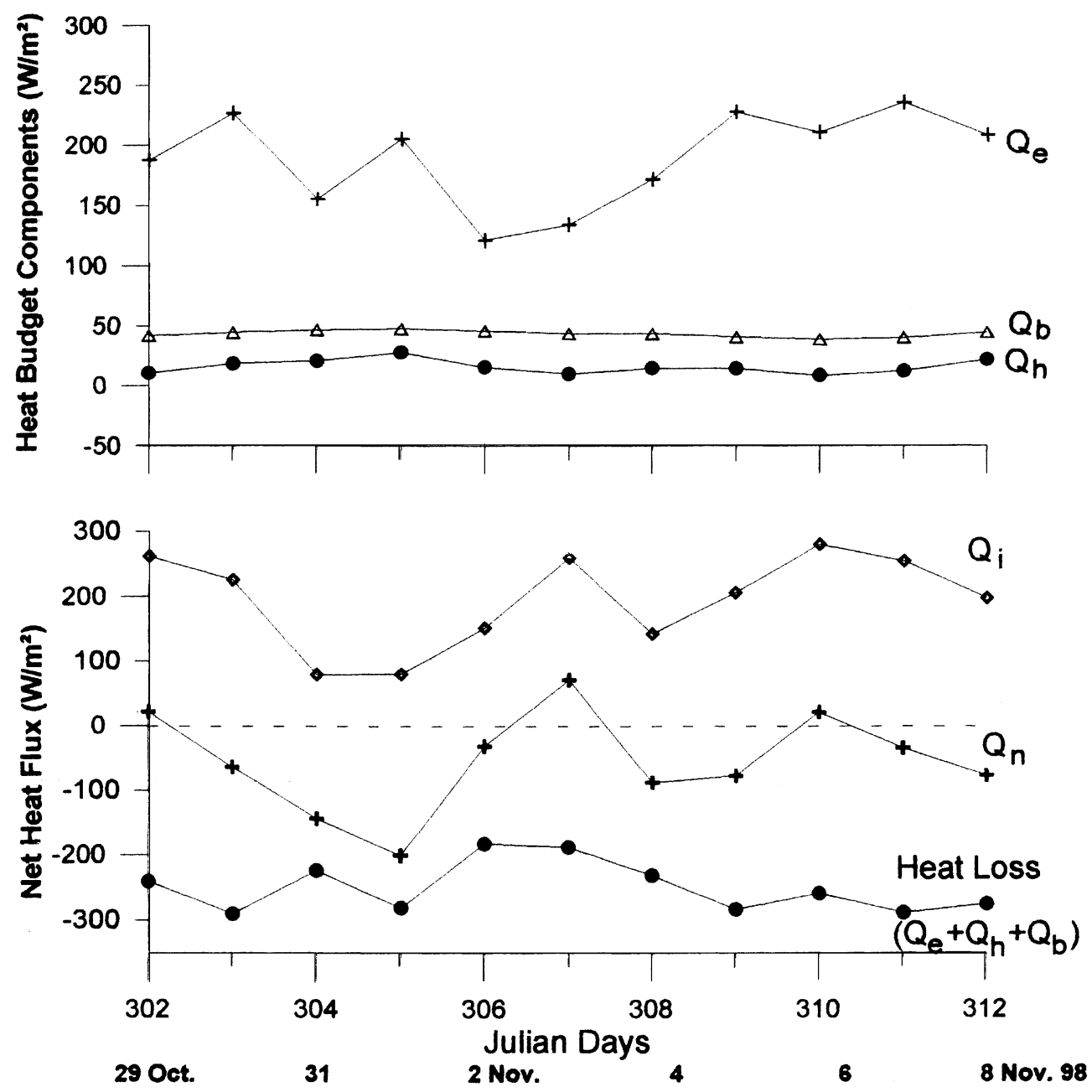

Figure 10. Along track daily variation of (a) heat budget components $\left(Q_{e}, Q_{h}\right.$, and $\left.Q_{b}\right)$ and (b) net surface heat flux $\left(Q_{n}\right)$. Incoming solar radiation $\left(Q_{i}\right)$ and total heat loss $\left(Q_{e}+Q_{h}+Q_{b}\right)$ during BOBMEX-Pilot.

The mean velocity of the northward flow is increased gradually towards north. At $200 \mathrm{~m}$ depth, (figure $8 \mathrm{~d}$ ) the measured currents describe the cyclonic flow as noticed in the geostrophic flow pattern at $200 \mathrm{~m}$ depth (figure $7 \mathrm{~d}$ ). The measured current vectors at the other locations to the west of $87^{\circ} \mathrm{E}$ indicate that the circulation becomes more cyclonic gyral with the depth but with the reduced speeds in upper $200 \mathrm{~m}$. The monthly diagnostic bulletins of climate (1998) for October and November, 1988 months show that this study area is witnessed with the incidence of low fluxes of Outgoing Longwave Radiation (OLR) which can be attributed as a result of increased cloudiness in ITCZ. However, the current vectors exhibited a rightward shift in direction with depth. Baroclinic current shear is noticed between 50 and $100 \mathrm{~m}$ depths. Recent results of ocean circulation modelling studies (Vinayachandran et al 1998, 1999) of the Bay of Bengal have shown the northward turning of IMC along $87^{\circ} \mathrm{E}$ in July itself and its axis of northward turning is found shifting progressively westward with the advancement of summer monsoon.

\subsection{Heat budget of the study area}

Surface meteorological observations (wind speed, relative humidity) obtained at $10 \mathrm{~min}$. interval are averaged daily and are shown in figure 9 along with daily average of Sea Surface Temperature (SST). On three days, the SST has reached higher values $\left(\sim 29.4^{\circ}-29.6^{\circ}\right)$. Relatively weaker wind speeds are encountered around 2nd November when the ship has been in the central part of the study area (figure $9 \mathrm{~b}$ ). The RH and sea-air temperature interface (TS-TA) shows trends similarly with a maximum value on 305 Julian day (1st November) (figures $9 \mathrm{c}$ and d). The specific humidity difference $\left(Q_{s}-Q_{a}\right)$ between the sea surface and air (figure 9e) varies between 6.0 and $7.5 \mathrm{~g} / \mathrm{kg}$ while the relative humidity changes between $75 \%$ and $85 \%$. The sea surface minus air temperature $\left(T_{s}-T_{a}\right)$ values vary between $1^{\circ} \mathrm{C}$ and $3^{\circ} \mathrm{C}$ indicating the instability in the atmospheric boundary layer over the study area. The dependence of SST on $Q_{s}-Q_{a}$ is quite evident.

The computed sensible heat flux $\left(Q_{h}\right)$ and effective back radiation $\left(Q_{b}\right)$ are nearly constant at $10-15 \mathrm{~W} /$ 
$\mathrm{m}^{2}$ and $45-50 \mathrm{~W} / \mathrm{m}^{2}$ respectively (figure $10 \mathrm{a}$ ). The daily variation of the latent heat flux $\left(Q_{e}\right)$ follows the daily variation of wind speed (figure $9 \mathrm{~b}$ ) and attains a minimum value of $125 \mathrm{~W} / \mathrm{m}^{2}$ on 306 Julian day. The latent heat flux dominates the total heat loss in the study area (figure 10b). The AWS global solar radiation $\left(Q_{i}\right)$ varies from a minimum value of $80 \mathrm{~W} / \mathrm{m}^{2}$ to a maximum of $300 \mathrm{~W} / \mathrm{m}^{2}$ during study period. The low values of $Q_{i}$ on 304 and 305 Julian days are associated with overcast skies. The net heat flux $\left(Q_{n}\right)$, a residual of insolation and total heat loss, is negative during most of the study period and the mean net heat flux is about $-55 \mathrm{~W} / \mathrm{m}^{2}$. This suggests that the southern Bay of Bengal, on an average, loses heat energy across the sea surface during OctoberNovember when the study area is under the influence of southward moving Intra- Tropical Convergence Zone (ITCZ).

\section{Conclusions}

- Southern Bay of Bengal where the summer monsoon is quite active during October - November, 1998 is generally seen as a region of net heat loss from the sea surface to the atmosphere promoting convective activity in the latter.

- The upper ocean circulation (0-200 m layer) in the study area shows a northward turning of IMC along $87^{\circ} \mathrm{E}$ under the influence of the depth-increased cyclonic motion and this cyclonic gyre could be attributed to the wind shear associated with ITCZ which is present in the study area during the observational period.

\section{Acknowledgements}

The authors wish to thank Dr. E Desa, NIO, Goa, and Dr. (Mrs) Sulochana Gadgil, IISc, Bangalore, for their encouragement to take up the BOBMEX-Pilot project. We also acknowledge the Departments of Science \& Technology (DST) for the financial support and Ocean Development (DOD), Government of India, for providing necessary ship time for this programme. One of the authors (CVP) expresses gratitude to DST for providing project assistantship. This is NIO contribution No. 3566 .

\section{References}

Climate Diagnostic Bulletin of India - Seasonal Postmonsoon (October - November), 1998, (Special Issue No. 11) India Meteorological Dept., India, pp 19.

Cutler A N and Swallow J C 1984 Surface currents of the Indian Ocean (to $\left.25^{\circ} \mathrm{S}, 100^{\circ} \mathrm{E}\right)$. Surrey: Institute of Oceanographic Sciencies (United Kingdom).

Gopalakrishna V V, Pednekar S M and Murty V S N 1996 Indian J. Mar. Sci., 25 50-55

Murty V S N, Ramesh Babu V, Rao L V G, Charuta V Prabhu and Tilvi V, 2000 Proc. Indian Acad. Sci. (Earth Planet Sci.), (this issue)

Murty V S N, Sarma Y V B, Rao D P and Murty C S 1992 J. Mar. Res. 50 207-228

Murty V S N, Suryanarayana A and Rao D P 1993 Indian J. Mar. Sci. 22 12-16

Murty V S N, Sarma Y V B and Rao D P 1996 Proc. Indian Acad. Sci. (Earth and Planet. Sci.) 105 41-61

Sarma Y V B, Murty V S N and Rao D P Thermodynamics of the oceanic and atmospheric boundary layers over head of the Bay of Bengal during the southwest monsoon of 1990; NIO Technical Report No. NIO/Tr-3/97, 1997, pp. 35.

Sarma Y V B, Ramarao E P, Saji P K and Sarma V V S S 1999 Oceanologica Acta. 22 453-471

Stevenson J W 1982, Computation of heat and momentum fluxes at the sea surface during the Hawaii to Tahiti shuttle experiment; Univ. Hawaii, Honolulu, Hawaii.

Suryanarayana A, Murty V S N and Rao D P 1993 Deep-Sea Res., 40 205-217

Varkey M J, Murty V S N and Suryanarayana A 1996 Oceanography and Marine Biology: An Annual Review., (eds.) A D Ansell, R N Gibson and Margaret Barnes, (UCL Press) 34 1-70

Vinayachandran P N, Masumota Y, Mikawa T and Yamagata T 1999 J. Geophys. Res. 104 11077-11085

Vinayachandran P N and Yamagata T 1998 J. Phys. Oceanography. 28 1946-1960 